\title{
ADDRESSING POLYPHONICITY OF DRAMATIC DISCOURSE
}

\section{Valeriia Koroliova}

\section{INTRODUCTION}

The process of artistic communication predetermined by social, communicative and normative factors directs contemporary researchers to the analysis of a literary text in a discursive aspect which reorients linguists to study the pragmatic factor in the text as a manifestation of the communicative intention of an addressee and recipient.

A specific kind of artistic discourse, which is in turn a modification of Ukrainian national discourse, is defined by linguists as dramatic discourse. However, in our opinion, dramatic discourse having only its characteristic features deserves to be singled out and analyzed as an independent discourse which by categorical features is close to dialogical and theatrical (stage) discourses. Generalized modern interpretation of discourse implies enrichment of a text at the discursive level with characteristics due to extralinguistic factors that enhance its pragmatic openness and transform procedurality from an immanent feature into a differential feature of discourse.

Dramatic discourse can be considered a mixed type of communication. On the one hand, it is personality-oriented because it functions in everyday communication, and on the other hand, it is statusoriented because it has an institutional character due to its connection with stage (theatrical) discourse. In addition, modern scholars point to the importance of status role of characters emphasizing the dependence of semantics of a play on social status to which they (characters) are empowered by a playwright. All this determines the specificity of dramatic discourse addressing and the actualization of "double addressing" concept.

The ambiguity of communicative status and the complex system of dramaturgic text addressing lead to different definitions of "double addressing" concept. Researchers of postmodernism trying to counteract the confrontation of high and mass cultures declare double addressing of any literary text as the principle of postmodernist writing aimed at both an average reader and an intellectual. Some researchers (I. Ilyin, L. Strelets) perceive double addressing as an increase in the communicative load of internal communication system due to a lack of explicit dialogue between 
an author and a reader, which makes both characters and readers become recipients of conversational turns. In this case not only are conversational turns marked with relevant remarks, but also any dialogues and monologues of characters are perceived as addressed to readers. While agreeing that the fictitious communication of characters is subordinate to author's main dialogue with a reader, we note that a more accurate interpretation of double addressing, in our view, is its interpretation within the framework of external communication, expressed in paratext elements of a play, adressees of which are aviewer and a director. It should be noted that viewers or readers do not act as direct addressees, but rather as an observer who watches the events unfolding in a play, whether on stage or in dramaturgic text

Dramatic discourse caused by specifics of stage communication is characterized by double addressing which distinguishes director and reader as direct addressees of paratext elements of a play, including remarks. In our opinion, it is interesting to analyze dramaturgic addressing on the material of contemporary Ukrainian dramaturgy which is characterized by a number of specific features, namely: lack of clear local determination of dramaturgic works which causes a decrease in author's communication party at the beginning of a play; inclusion of extra-literary elements to a dramaturgic text, immorality, appearance of marginal characters all increase the dialogicality of contemporary dramatic discourse and affect the paratext component of plays; genre experiment that characterizes modern dramaturgic process allowing a playwright, despite canonical limits of artistic possibilities of a drama, to apply structural extension and functional complication of play's remark layer giving it a narrative feature.

Thus, separation from classical dramaturgic design, genre experiments and implementation of creativity in the text of a play determine the specificity of communicative system of contemporary dramatic discourse. The consequence is destruction of the boundaries between external and internal communication within a text of a modern Ukrainian play.

\section{Addressing as discursive category}

Discursive categories characterizing speech not only as a means of transmission but also as the formation of thought differ from textual categories in their procedural nature, adherence to the criteria of selection of non-linguistic context, the situation of speech creation. Considering the interpretation of modern linguists discourse as a consideration of all the 
spectra of speech functioning in its situationally-communicative, pragmatically-social and culture-historical aspects, we perceive I. Shevchenko's concept as an appropriate one. According to it categories are divided into discursive, separated into cognitive (informative and cohesive) and communicative (intentional, addictive, situational) and meta-discursive, expressed by means of designing discourse as a process - its communicative strategies and tactics, genre-stylistic peculiarities discursive roles ${ }^{1}$.

Recent linguistic studies of dramatic discourse do not pay much attention to implementation of textual categories in plays. Analyzing the text-forming potential of communicative strategies, O. Krynytska presents anthropocentricity, informativeness, intentionality, modality, membership, dynamism, cohesion, coherence, integrity as text categories of a dramaturgic work ${ }^{2}$.

N. Safonova within the limits of a dramaturgic work distinguishes such specific textual and discursive categories as continuum, dialogism, expressiveness, emotionality, anthropocentricity. However, the categories of expressiveness and emotionality that the author interprets as "a means of creating an artistic image, revealing the inner world of actors, a way of expressing the modal load of the whole text" are characteristic of any work of $\operatorname{art}^{3}$. Just like anthropocentricity as a tripartite explication of subjective-modal coloring of a text (with levels of author, characters, reader) is peculiar to other works of art.

Given the available linguistic studies all discursive categories can be divided into universal (invariant), which are characteristic of the vast majority of discourses, and specific (individual), characteristic only of a particular discursive variety. In particular, modern linguists cite such discursive categories as individual: within the limits of Internet discourse - virtuality, accessibility, multimedia, hypertextuality; within the limits of political discourse - agonizing, aggressive, ideological; within the educational-pedagogical discourse - paraphrasing, polysemioticity, integrativeness.

${ }^{1}$ Shevchenko I. S. Discourse and its categories. Bulletin of Kharkiv National University. 2011. No. 973. P. 8.

${ }^{2}$ Krynytska O. I. Implementation of communicative strategies in artistic text. Ivano-Frankivsk, 2009. P. 5.

3 Safonova N. M. Subjective modality in dialogue and polylogue of contemporary Ukrainian drama. Donetsk, 2006. P. 11. 
An important category is that of an addressee expressed in the program's built-in textual addressing to a hypothetical reader which should help optimize the understanding and integration of a text by a real recipient. According to A. Vorobyova the category of addressing is interpreted as a text feature through which author's idea of the potential addressee and the peculiarities of his/her interpretative activity are verbalized ${ }^{4}$. The structure of discourse conditioned by presence of an addressee and an addresser explains the importance of the category of addressing that comes to the fore in the process of perception of a work. The peculiarity of dramatic discourse is the sign of double textual addressing because, thanks to remarks, plays always have two addressees: one is the playwriter and the other is the viewer. We should note that a viewer or reader does not act as a direct addressee, but as an observer who watches the events unfolding in a play, whether on stage or in dramaturgic text.

A play's director is an addressee who is eliminated from the direct text in play's paratext zone and is obliged to facilitate the implementation of play's dramaturgic design. In this case areader who turned to any contemporary play is defined in the structure of dramatic discourse as an addressee, who receives information aimed at both a viewer and a director.

Addressing significantly affects the division of dramaturgic space. The external nature of text division expressed by the presence of structural part is caused by the peculiarity of human world perception, so a speaker tries to achieve the success of text communication through adequate division of the proposed text. Among the means of discretion are: utterance, paragraph, chapter, section, etc. - at the formal level; sentences, transphrasal unities, microtexts, periods - at the semantic level.

Double addressing determines the peculiarity of formal structuring of contemporary plays. Dramaturgic literature text, as opposed to epic and lyrics, focuses not only on the verbal reproduction of a picture of reality recorded in writing. The basis of the play is another artistic and aesthetic principle of the image according to which the text of a play is designed for reproduction on stage by real people (actors), which motivates the specifics of its language organization. The stratification of dramaturgic fabric of a work into replicas of characters and author's remarks

\footnotetext{
${ }^{4}$ Vorobyova O. P. Text categories and addressee factor. Kyiv: Higher School,
} 1993. P. 117. 
determine the specificity of the category of discretion in dramatic discourse.

The importance of extra-lingual factor in a drama justifies the interruption of characters' conversational turns by author's narratives, which constitute the paralinguistic accompaniment of characters' speech. It should be noted that replicas and remarks of a dramaturgic text are distinguished not only graphically (presentation of remartks in brackets, font reduction, use of italics), but also stylistically. In this case we can talk about the appointment of the former (replicas) to characters, and the latter (remarks) - to a director, emphasizing the addressing of the entire text to a potential reader.

This situation transforms the dialogicality of dramatic discourse which is due, according to A. Hubersfeld, to the fact that conversational turns are always generated by a communicative situation, always addressed to someone ${ }^{5}$. Double addressing determines both the internal and external dialogical nature of drama. Internal dialogism is peculiar to any artistic discourse, since in its structuring the elements "author - text reader" are always involved. Ocassionally linguists even identify the concepts of "dialogue" and "discourse" defining discourse as a communicative act that involves two roles - speaker and addressee. In this case, in dramatic discourse the role of a speaker is performed by an author, and the role of an addressee by a reader. Perceiving dialogue as a two-way communicative process in which each participant of a dialogue is a subject and simultaneously an object of speech influence, a reader becomes a passive participant of dramatic discourse, which, however, does not diminish his/her importance as a communicator.

External dialogism is the dominant feature of dramatic discourse. The implementation area of external dialogism is communication of characters of contemporary plays. External dialogism is also characteristic of everyday discourse, whose stylization, in fact, is dramaturgic dialogue. However, a dramaturgic work is characterized by speech "engagement" in which reader is already involved in the structure of a text through author, who takes into account tastes of potential recipient during the creative process, which is why the "engagement" of a dramaturgic work causes the "concentration" of dialogism in personal communication compared to everyday communication dialogues. External dialog is motivated by

${ }^{5}$ Yubersfeld A. Instead of preface. Pavi P. Dictionary of theater. Moscow: Progress, 1991. P. 7. 
support of communicative activity of a character by author's intention. In this case, even the monologue speech of a characher, who is on stage, contains elements of dialogue. A monologue from P. Arye's play "Colors" provides an example of it:

A woman in white. They took away the father. I have never seen him again. At school-byname -children of the enemy of the people. What kind of people? (Sits on the floor or cube). My mother was taken away, beaten and raped every night. Wife of the enemy of the people. She got pregnant without a father. The boy was born dead. I don't know if I could hate him? No! Cross out the last one! ... I would love him more than myself... Perhaps, in many respects, I am also to blame... I used to sew quite well, but I did not finish my life very well. Everything passed by just like in tango. (Upward commanding tone). Maitre! Size 2/4, the pace is moderate!

The analyzed separate monologue from P. Arye's play "Colors" spanning several pages of text proves the existence of explicit markers of dialogicalness in monologue speech (appeals, interrogative and imperative constructions). Internal dialogue of a play taking into account addressee factor determines the presence of expressions of external dialogue in character's speech.

In this case we consider appropriate to use the term "polyphonic" to refer to a category of dramatic discourse that reflects the specificity of addressing in contemporary plays. Any character's replica having a dual direction is defined by polyphonicity: aiming at both a partner in personal communication and a potential reader.

In the same way, author's remarks are intended for both writer and reader since drama as a kind of literature requires paratextual remarks for director. On the other hand, the choice of drama's author for implementation of a creative plan is motivated "not so much and not only "to play" it, but because he/she needs exactly this and no other form of verbal-artistic image" . It should be noted that lack of narrative in a dramaturgic text and the imposition of a double address on a reader, who plays the roles of both a director and a viewer, enhances the importance of imgaination in the recipient of a contemporary play. In this case a reader needs to imagine a dramaturgic effect, reconstruct the missing elements in a text, which leads to a successful perception of a dramaturgic text and

${ }^{6}$ Vinokur T. G. On the language of contemporary dramaturgy. Language Processes of Contemporary Russian Fiction. Moscow: Science, 1977. P. 137. 
author's intention implementation. Lack of detailed descriptions of interior, portrayal of characters, depiction of internal status of characters in the text of a play enhances the importance of receptiveness of reader's perception, usage of his/her intuition and creativity.

Thus, the category of addressing significantly influences both formal division of a dramaturgic text and overall sense of polyphonicity, even in monologically solitary characters' replicas. This multi-level structuring of addressees leads to a stylistic stratification of the text of a play: a text aimed at a director should be simplified, emotionless while characters' parties should be filled with emotional and evaluative connotation, and they become the epitome of authorial talent. However, modern drama captures blurring of the boundaries between the two text registers which eliminates stylistic marking of addressing.

\section{Paratext as means of explisit addressing}

A dramaturgic text illustrates the pluralistic addressing of paratextual components of a play most clearly. In scientific community the term of "paratext" as a designation of non-textual elements, which, taking the limiting place, significantly affect the complex nature of the relationship between the text, author and reader, was introduced by G. Genette ${ }^{7}$. The parts of a play in which an author can directly address the production are a list of characters and remarks.

The list of characters is an important means of direct expression of an author's intentions which modern playwrights use to inform a director, predict and interest a reader. The list of characters is a manifestation of author's communicative activity, explicitly directed at a reader as an object of playwright's speech influence which determines the level of deployment of the characteristics of each character and the actual tone of that characteristic.

According to the degree of author's description detalization of characters and pragmatic potential we consider it appropriate to offer a distinction between minimized, concise and detailed lists of dramaturgic characters. At times the lists of characters are minimized, devoid of not only author's character traits, but even character nominations. For example, in E. Kononenko's play "Call man" we have the following description:

${ }^{7}$ Genette G. Paratexts: thresholds of Interpretation. Cambridge: Cambridge UP, 1997. P. 2. 


\section{List of characters:}

$\mathrm{He}$

She

People in episodes and on the phone.

To those with a minimized level of characteris description we also include lists of characters that enumerate only neutral character names that are devoid of pragmatic load in semantics. For instance, the following list is presented by T. Ivashchenko in the comedy "Ordering Love":

List of characters:

Vira Mykolayivna

Kyrylo

Nadiia.

Priority in the studied dramaturgic works is concise authorial descriptions of characters in the list in which a playwright selects only one trait, favoring family, age and social characteristics, e.g.:

List of characters.

Oksana Pavlivna Pokotylo, 43 years old

Olha Pavlivna Karpenko, her sister, years old

Tayisiia Nazarivna Kostenko, their mother, years old

Nadiyka and Sonia, Olha's daughters, 6 and 4 years old (H. Lehka "Pornography").

Another instance is the list of N. Doliak's play "Gastarbeiter seasons" (age, family and social characteristics, description of appearance, psychological evaluation) which has detailed author's characteristics:

List of characters:

Sasha Alex - a fragile woman, 45 years old. Tries to look much younger. She succeeds. Fun and energetic person. Former dancer. Woman of fashion.

Katia-Katarina - at most twenty-five years old. Tall, looks like a model, though she dresses very clumsily, always with a sad look. Former sportswoman.

Olena-Helena - an elegant delicate lady of middle age. She is fluent in German - in the past a teacher. Widow.

Kolia-Helen's son. Candidate of Engineering, looks like a mouse, an elderly slender man.

Tamara - his mistress. Too beautiful as for such a man, a woman who resembles a Japanese statuette. 
Detailed lists of characters make it possible for a playwright to contact a director directly, to draw attention to those character traits that are important for revealing author's position and concept of a play.

In lists of characters at times we have direct addressing only to a director, for example:

$C A T-$ man in black

PUSSY CAT - woman in white

$B O D Y$ - speechless and overall "less" (actor is not required) (N. Nezhdana "Loneliness suicide").

Another parathex element relevant to addressing is a remark which should be interpreted as a conversational turn of author's speech party in author-reader dialogue. In this case all narratives perform either a conversational turn function or a narrative function which has recently become widespread in contemporary dramaturgic texts. The typology of remarks is still not unified and it is ambiguous and vague in the lexicographic literature. We consider it appropriate to classify remarks by their structure and communicative functions. Let us analyze the proposed typology of remarks on specific examples.

1. A replicated representative. Representational function is traditional for a remark ${ }^{8}$ because this feature allows recipient to perceive extracurricular reality without involving the event sphere. Representative remarks state physical, mental state of participants in dramatic discourse.

A shortened replicative representative is expressed by a sentence with a partially filled out scheme in which character's name is often a subject and the predicative function can be performed by a conversational turn, e.g.: Valerii (turns to Olha). For all saints and sinners, keep quiet! (A. Bahrian "Treat me with nuts"); Tania (looking at her watch). Twenty minutes left (O. Viter "Station").

A representative remark expressed by an ellipse for highest possible syntactic compression is a component of a complete sentence that is consistent with the components of a conversational turn and character's name, e.g.: Yan (to Valeriia). You also need to leave. It will be better (V. Tarasov "Love Hunting Season"); Dubelt (to a Servant). Thank you, my friend (S. Rosovetskyy "Shevchenko under court").

A non-shortened replicated representative has the form of a single complete two-sentence sentence in which a character may not even have a

8 Baklanova A. G. Linguostylistic characteristics of drama as text type. Moscow, 1983. P. 3. 
communicative initiative, but his/her actions stated in a conversational turn are a direct reaction to the previous replica. Example:

Clavdia Semenivna. Go.

Grandma Hanna goes out (V. Kanivets "I want to be the president").

2. Replicated descriptor. Remarks with a descriptive function are not intended to be a statement but rather a description of a phenomenon, event, object. Such footnotes at most indicate the interpenetration of author's communicative party to communicative activity of characters. For example: Woman (through her teeth). You can say just Vira... Heorhiivna (N. Nezhdana "The one who opens the door"); Olena (playfully). Hopefully it's not the only nail the house holds? (O. Pohrebinska "I know five boys' names ...").

3. Narrative. It represents providing dramatic action with a narrative character through introduction to a play of fiction elements that indicates author's intention of monologizing. A narrative remark contains as much information as possible about the stage production. A noncommon narrative is expressed by one or two sentences that have no more than two predicative centers. Example:

Andrii. Why? I am drinking, I've just drunk three cups today ...

Andrii sits at a table. Halyna is making tea (N. Nezhdana "When the Rain Returns").

Syntactic construction with more than two predicative centers is characterized as a widespread narrative remark which is interpreted as author's communicative party, which can contain not only descriptions of events but also reflection, evaluation and expression of a playwright. For instance:

They drink champagne ... Marital life begins. Franko sits down to work. Olga cleans the house (T. Ivashchenko "The secret of being").

Further complication of widespread narrative remark by author's intentions leads to fictionalization of remarks. Example:

Change of light. Barely audible, gradually approaching, "Eternal memory!" Sounds. When the tune gets tight behind the stag it enters the stage and the hall along with the funeral procession. They carry a small white coffin. Behind the coffin there is Lira with a dark veiled head, Semirid and all the villagers. Father Antoni and Lira stop on stage and watch the procession. And "Eternal Memory!" weeps with unspeakable pain, combining notes of sorrow and... optimism. This two-word requiem has become one of the most ingenious works of Christianity ... The unspeakable longing of man for man, the complaint of humanity to the 
cruelty of death which does not have any mercy ... (M. Nayenko "To Heaven - on foot").

Such narratives determine further development of a play, structure dramatic discourse in general. Fictionalized drawings are aptly treated as epic miniatures that, apart from traditional features, are marked by meaningful elegance and compositional design ${ }^{9}$, for example:

"Benign Thursday" dance show. (It is such a rare day in life. People can't help enjoying themselves. A boy is cheering happily, a businessman goes out of town to look at a house with a garden. Old people sit looking away from a distance, sadly recalling that at their young age all the days were like that. Horses were lying on a green meadow. The chickens were cackling, waving their wings in the sun. A happy day when one manages everything). Joseph-Maria's stall. Master and Mak (S. Lazo "This is Life!").

Fictionalized narratives at most demonstrate double addressing of dramaturgic discourse since such intrusions of author's speech activity into the textual array of a play contain an explicit attempt to influence a director connected with the perception of hidden meanings of a play. Example:

Intrigue continues to evolve into the best examples of a classic detective. After a while the armored door opens. First and Second roll out a large trunk on wheels. Looking around they run to the front door slightly opening it (J. Vereshchak "Stefko sold to mormons").

It is easy to notice the difference between these fictionalized remarks and the traditional ones which fulfill their primary function of ascertainment and are aimed at a double addressee.

Occasionally fictionalized notes from the implicitly expressed form of author's speech party become a real explicit author's speech activity. For example, in V. Rybachuk's play "Solo for Two" the author using a conversational turn presents his own thoughts-appeal to a director about the fate of his dramatic work, warning the object of communication about possible consequences of stage embodiment of the play:

This is not the final version of action development... The action may develop in a different way: as each of us imagines it, or may have already "played" in our lives. That play is not a performance. I am not sure that a director who will (hopefully) ever turn this play into a performance will not

9 Zaitseva I. P. Poetics of contemporary dramaturgic discourse. Lugansk: Alma Mater, 2007. 332 p. 
be homosexual, zoophile or, for example, a rodent, and the play text will not only perceive the play through the lens of his physiological (or party) preferences. so when nymphomaniacs in knightly armor will run after a naked man on stage - do not attribute this to me, and when an actor says, "This is all a lie" and the text does not contain it, it will not be the opinion of an actor, mine or yours. Our thoughts do not always coincide.

In this example author's speech activity is quite real and reader's party remains virtual. Author is not acting as a mediator between reader and event trying to program recipient's emotional response, but rather as the subject of communication in the dialogue with reader. Unlike double textual addressing, which is typical of play texts (there are always two addressees in play texts: director and viewer), the shown remark is explicitly directed at reader as the object of author's speech influence.

Conversational turns with explicit markers of appeal to a viewer have a special communicative load. Such conversational turns lead to destruction of the so-called "fourth wall" which delimits the fictional world of drama from audience and is labeled with word forms like to the viewer, to the audience. Example:

1. Den (to the public). And when angels lose their feathers, does it hurt or not? Does anyone know? No? (N. Nezhdana "Deal with angel").

2. (Green and Brown lower their heads ... In the frenzy they smear makeup on each other's face and body. They turn to the audience).

Green and Brown. Please!

Voice. What do you think about this? (A. Vyshnevskyy "The Difference").

3. A sadist. (To the hall). Hush... Keep quiet, children, quiet because you will be in trouble (J. Vereshchak "Uniformist").

It should be noted that contemporary authors introduce such remarks to the structure of a dramaturgic text to engage reader in dramaturgic discourse as an accomplice to the play's co-author. At times further character's replicas may even mimic character's direct dialogue with viewer with the latter's alleged replicas. For instance:

1. Similarity. Well, how do you find the fairy tale? If it weren't for me, then it wouldn't exist. Do you like it or not? I can't hear it, louder! Did you like it? Well, then come again and bring to our underwater kingdom all friends who have not seen it. Be therefore rich as the Earth, and healthy as the water! (V. Serdiuk "Adventure Day, or June 32").

2. Overseas-looking sir (addressing the hall). Don't you know where the authorities are located here? I have to keep my grandfather's will and give this treasure to the local state. No? Don't know? Hey, are 
you walking? And what will I do with all this? Please help. Well, someone? Maybe you, a young man? Either not. Horror, what a proud nation, and nobody wants gold here already... (V. Serdiuk "Adventure Day, or June 32").

Such expressions of explicit addressing are placed by an author in strong positions in a dramatic text, namely, at the beginning or end of a play. Appeal to a viewer / reader of a play may not be on behalf of a character, but be rather directly authorial and contained in optional drama components, such as epilogue or prologue. For example, S. Brama in the play "Pig liver" presents the following epilogue:

There will be no applause today, because together with you we honor the moment of silence of all victims of unjustified cruelty.

N. Bondarenko in the play "Sky colour chrysanthemum" addressing reader in the prologue explains the structural specificity of the drama, which encourages addressee to the perception of the work:

The play is based on the "Mobius tape" in dialogue with the Japanese writer Rennyo. The combination of Japanese and Ukrainian cultures gave an unexpected effect, which can be felt reading the play.

Place of direct appeals to a viewer / reader in strong positions of the text provides highlighting the most important meanings of a text, focusing attention on the most important, enhancing emotionality and aesthetic effect, as well as demonstrates the importance of an addressee in dramatic communication, his/her permanent influence on a playwright creating a play.

\section{Settings as specifically addressed dramaturgic text}

Separating the main body of a dramaturgic text which presents characters' internal communication as the stylization of live oral speech and the so-called "texts in the text" which make up paratext elements of a play (title, subtitle, list of characters, remarks, etc.), the researchers highlight introductory remarks as a prime example of a playwright's direct appeal to a director. Such introductory (mise-en-scene, introductory) remarks are called settings by linguists, they are means of reproducing the "naturalness" of a situation, the ease in actor's moving on stage, the conformity of all elements of the stage space decor with the appearance of actors ${ }^{10}$. It is the setting which is the most striking example

10 Kubriakova H. S. In search of language essense: Cognitive Studies. Moscow: Badge, 2012. 208 p. 
of dramaturgic text double addressing. Communicative function of these remarks is quite significant, as they affect the success of author's embodiment, compensating for the lack of information on the conditions of internal communication of characters, due to the specificity of dramatic discourse, devoid of narrative. Such settings are traditionally distinguished purely linguistically, verbalizing in laconic sentences with verbal expressions of meaningful content the communicative task of which is to announce presence in surrounding reality as a whole or in its individual fragments of corresponding objects with their characteristic features. Example:

1. Hospital ward. Late Night. There is a large window on the right. Left door. There are two wheelchairs on the backstage. Lysy and Borodan are sleeping there (V. Serdiuk "Merciful sister").

2. Bohdan's apartment. Living room. Home environment. Table with chairs.

Poliusia pulls Max's hand from the doorstep. Dressed as modern "progressive" youth (A. Bahriana "Angels have something from evil").

In the studied plays addressing of remarks to a director proves the usage of theatrical terminology in the structure of a dramatic text, for example:

1. All objects and decorations are present on stage at the same time. Shared space. Everything is conditional. Stage. Even actors. After all, they are also here on stage, but they are not visible. Spectator will see them when needed. They will all remain on stage until the end of the play, becoming actors for a while and spectators of their colleagues' mise-enscenery on stage for a while... They will come to life and become active when it is their turn and while they are spectators as well the only difference is that they are sitting not in the darkness of orchestra stalls, but in the twilight of the stage (O. Zhovna "Experiment").

2. It is half-dark. The curtain is open. Room. Decorations are conditional - with replacement of several detail the room is transformed into any other room specified in the play. On the left side of the front stage there is a chair and a coffee table - this is Darina's place, illuminated by a spotlight. There is a light, quiet, slightly sad melody (leitmotif of the play) (N. Uvarova "The Undying Heart").

Settings reproduce reality both in reader's and director's imagination with subsequent implementation for spectator. It is for director that playwright's directives are introduced, the most important of which are visual and sound aspects. The visual aspect is the layout of 
stage, decorations, lighting, details, costumes for actors. Here are excerpts from several settings that illustrate the visual guidance:

1. Large living room, tastefully decorated in a modern studio. On the walls there are pictures by Yakov Hnizdovskyy "Cat's Dreaming" and "Pink Beech" (O. Mykolaychuk "Flower for three months").

2. Evening. The front door bangs. Jack in a short jacket and jean enters the room. He puts a bottle on the table, opens it, pours it into a glass and drinks (S. Shchuchenko "Noble Don").

3. The stage is divided into three parts. Almost the whole wall is occupied by a painting. In the hall there is a table for a chairman of the meeting, chairs for participants. At the end of the hall there is a door to the compartment where the costumes were stored, and now there are tables with bottles and dishes for the feast (A. Naumov "Department for the decent").

Sound implementation aims to outline the sounds of nature, city, voices behind the stage, special effects. For instance:

1. Wind whistling. The passage from Dmytro Dontsov's article about O. Teliha "Poetry of Fire Borders" is read in a male voice (A. Bahriana "Sadness and Passion").

2. Night. Some strange sounds are heard. They are joined by voices of trembits (T. Ivashchenko "Secret of being").

3. Light goes off, hissing of carriage doors can be heard, the clatter of carriage wheels is distant and dog's barking is very close (V. Danilenko "Money for Ionesco").

Addressing a director is also indicated by the presence in remarks of author's comments which cause variations during the production of a play which is marked in remarks by corresponding lexical items. In this case author allows future director to select the details that he/she thinks will be the most suitable for the reproduction of the scene and the course of a drama. Example:

1. Park of a clinic for mentally ill. A Cropppar-like man in pajamas sits in a wheelchair and mutters something gibberish (perhaps Sanskrit). Nietzsche walks nearby - in a suit, with a stick - but it is not clear who he is (T. Kytsenko "The three Nietzsches").

2. Den is at home, collects a bag - there is a wig, makeup, a hare mask in it. Castle opening is heard. Den abruptly hides everything in a bag, a bag in a box, and the latter hides, for example, under a bed and hangs something (it may vary) (N. Nezhdana "Deal with angel").

3. On the stage there is a movable table with crushing traces of multi-day drinking (appropriate minimum of props - for theater 
consideration). Almost under the table lies a man. This is Miryk. He wakes up. Sits down (O. Slipets "Chronicles of the first year").

At times such remarks are used by author at the same time for selfpresentation and creation of a certain emotional mood, for example:

A fire is made. Certainly there may be problems with the fire department of the theater - but still some kind of fire would be desirable (N. Nezhdana "Loneliness suicide").

It should be noted that structurally settings of contemporary Ukrainian plays are quite diverse: from a detailed description of interior with clear authorial comments to an abstract rendering of the scene without specifying the stage embodiment. In this case we trace the dependence of syntactic structure and stylistic design of remarks on the function of this element of a play, allotted by author. The more specific and transparent setting addressing is to director, the more structurally easier and expressively neutral is the text of setting. Playwright's deviation from the classic for a drama addressing to director causes complication of syntactic organization of setting and actualizes the detection of author's origin in the text of remark. Let us compare two mise-en-scene settings that were given at the beginning of a play:

1. Ivan and Ivanna's apartment. In the middle there is a corridor with an entrance door. On one wall there is a large chandelier, on the opposite one there are clothes hangers. Beneath the wall there is a brush stand. To the left of the corridor there is a toilet, a bathroom and a kitchen. The kitchen includes a refrigerator, stove, numerous cabinets, a table and a seating area. To the right of the corridor there is a room. The room has bookshelves, a wardrobe, a large sofa. There is a desk with an armchair on the couch, a computer on the desk. In the corner by the window there is a TV. In the middle of the room there is a large carpet (A. Shamayeva "Last chance, or how to spend leisure time correctly").

2. Deep darkness of the scene is torn apart by a long, white female cry that suddenly breaks on an incredibly high note. Gradually intersecting light breaks through concentrating on the cramped female body that freezes into the floor, there is another figure hovering above - a shadow of a person or a human-shadow, a medium - a perennial manifestation of instantness - a child... a girl... a woman... a witch without signs of time... person ... A half-dark room. Blurred lines blur space - half-dream ... half-life ... (L. Chupis "Pottery Circle Dancing").

The first excerpt is composed of structurally simple sentences with semantics of a statement that neutralize but accurately depict play's scenery. In the second example there are complex sentences, termination 
of phrases is punctuated by three dots, which conveys considerable emotional tension. In this case there are no specific notes for director about interior and the course of further actions in a play and indeed addressing to director itself is leveled.

\section{CONCLUSIONS}

Given the peculiarity of dramatic discourse perception in a communicative act (reading or stage embodiment) the situation of text perception, its structure we define drama text as the text of polyphonic addressing which is the sole link of communicative process between addressee and addresser. Thus, it can be stated that dramatic text is defined as a structurally heterogeneous text simultaneously represented by two forms of existence, written or staged, represented by both textual and paratextual components.

Dramaturgic text has double addressing expressed in paratext elements of a play, the recipients of which are viewer and producer. In particular, remarks are directed to director, characterized by structural simplification, clarity, presence of theatrical terminology. Leveling of addressing to director causes complication of syntactic organization of remarks, which in some cases demonstrate explicit involvement of reader in theatrical action. An important component of addressing to director is setting, structurally and functionally diverse.

Thus, contemporary Ukrainian dramaturgy captures numerous shifts in textual and paratextual elements regarding their traditional addressing. Replicas are directly addressed to reader in some places, paratext component becomes a stylistically colored expression of author's origin, which reorients $\mathrm{him} / \mathrm{her}$ from the classic form (emotionally, structurally mature, simplified) into a paradigmatically meaningful component of a play.

\section{SUMMARY}

Modern Ukrainian dramatic discourse is characterized by experiments with form and content which explains modifications in traditional addressing of a dramatic text. Traditionally paratext (footage, list of characters, etc.) addressed to the stage director has a simplified form and neutral styling; emotionally colored are the remarks addressed to actors that make up play's internal communication. However, modern play demonstrates erasure of these canons, transition to addressing director in the area of replicas, enhancing emotional part of a conversational turn. We also record changes in introductory remarks, socalled setings: appearance of stylistic changes in them, violation of clear 
instructions for director, expression of author's emotions and experiences. All this transforms, mixes pragmatically important parts of a play, modifying the addressing of dramatic discourse, making it polyphonic.

\section{REFERENCES}

1. Baklanova A. G. (1983) Lingvostilisticheskaya kharakteristika dramy kak tipa teksta [Linguostylistic characteristics of drama as text type]. Moskva (in Russian).

2. Vinokur T. G. (1977) O yazyke sovremennoy dramaturgii [On modern dramaturgy language]. Yazykovye protsessy sovremennoy russkoy khudozhestvennoy literatury. Moskva: Nauka, pp. 130-197 (in Russian).

3. Vorobyova O. P. (1993) Tekstovye kategorii i faktor adresata [Text categories and addressee factor]. Kiev: Vishcha shkola (in Russian).

4. Zaitseva I. P. (2007) Poetika sovremennogo dramaturgicheskogo diskursa [Poetics of contemporary dramaturgic discourse]. Lugansk: Al'ma-mater (in Russian).

5. Krynytska O. I. (2009) Realizatsiya komunikatyvnykh stratehiy u khudozhn'omu teksti [Implementation of communicative strategies in artistic text]. Ivano-Frankivs'k (in Ukrainian).

6. Kubriakova H. S. (2012) V poiskakh sushchnosti yazyka [In search of language essense]. Moskva: Znak (in Russian).

7. Safonova N. M. (2006) Subyektyvna modal'nist' u dialozi ta polilozi suchasnoyi ukrayins'koyi dramy [Subjective modality in dialogue and polylogue of contemporary Ukrainian drama]. Donetsk (in Ukrainian).

8. Shevchenko I. S. (2011) Diskurs i ego kategorii [Discourse and its categories]. Visnik Kharkivskogo natsionalnogo universitetu. № 973, pp. 7-10 (in Russian).

9. Yubersfeld A. (1991) Vmesto predisloviya [Instead of preface]. Pavi P. Slovar teatra. Moskva: Progress, pp. 7-9 (in Russian).

10. Genette G. (1997) Paratexts: thresholds of Interpretation. Cambridge: Cambridge UP.

\section{Information about the author:}

Valeria Koroliova,

Doctor of Philology, Assistant Professor, Head of the Department of Ukrainian Language,

Oles Honchar Dnipro National University 72, Haharin Ave., Dnipro, 49010, Ukraine ORCID ID: orcid.org/0000-0002-7482-0517 